\title{
ELECTRON MICROSCOPE STUDIES ON \\ SOMA-SOMATIC INTERNEURONAL JUNCTIONS \\ IN THE CORPUS PEDUNCULATUM OF THE \\ WOOD ANT (FORMICA LUGUBRIS ZETT.)
}

\author{
ALEX M. LANDOLT and HANS RIS \\ From the Institute for Brain Research, University of Zurich, Switzerland. Dr. Ris's present address \\ is the Department of Zoology, University of Wisconsin, Madison
}

\begin{abstract}
1. The corpora pedunculata of the wood ant (Formica lugubris Zett.) contain densely packed neuron perikarya which are separated by ultrathin glial sheaths. 2 . These glial sheaths are occasionally interrupted by round holes with an average surface area of $2.64 \mu^{2}$. The holes are designated glial windows since they represent intracellular gaps of glial cytoplasm. 3. The glial windows allow soma-somatic interneuronal junctions. Of all adjacent neurons in a selected neuron pool, only $42 \%$ were interconnected by such junctions. 4 . The intercellular space at the soma-somatic junctions has an average diameter of $30 \mathrm{~A}$; occasionally, it is collapsed and an external compound membrane ensues. The junctional membranes are characterized by the presence of a subunit pattern of cross-directional electron-opaque lines with a 50- to 70-A periodicity. 5. Morphological signs of chemical transmission are absent in these junctions. On the other hand, there is a striking similarity in structural organization between soma-somatic junctions and electrical synapses described in other species. Therefore, it is suggested that these cell contacts of the ant's "cerebral cortex" are another form of electrical junction. 6 . The close proximity of the junctions to the cell nucleus is noted. Its significance could not be ascertained. 7. The suggestion is made that glial windows may have dynamic properties and may intervene in the regulation of interneuronal transfer of information.
\end{abstract}

\section{NTROD UCTION}

The neuronal cell bodies of the corpora pedunculata (mushroom bodies) in the wood ant measure 5 to $15 \mu$ in diameter and are separated by glial cell processes which are from 80 A to $1 \mu$ thick (exclusive of membranes). Landolt (1965) has shown that these glial sheaths are not continuous, but are interrupted by areas of direct interneuronal contact. The present work is concerned with the morphological details of these junctions, and an attempt is made to answer the following questions: 1) What is the three-dimensional shape of these junctions? Are they gaps between or within glial cell processes? 2) What is the fine structure of apposed neuronal membranes? 3) What is the possible functional significance of these junctions?

\section{MATERIAL AND METHODS}

Wood ants (Formica lugubris Zett.) were anesthetized with $\mathrm{CO}_{2}$ and the supraesophageal ganglia fixed with potassium permanganate $(3 \%$ in 0.071 м veronal-acetate buffer, $\mathrm{pH} 7.4$ ) or with glutaraldehyde (6\% in $0.024 \mathrm{M}$ sodium phosphate buffer, $\mathrm{pH} 9.4$ ) 


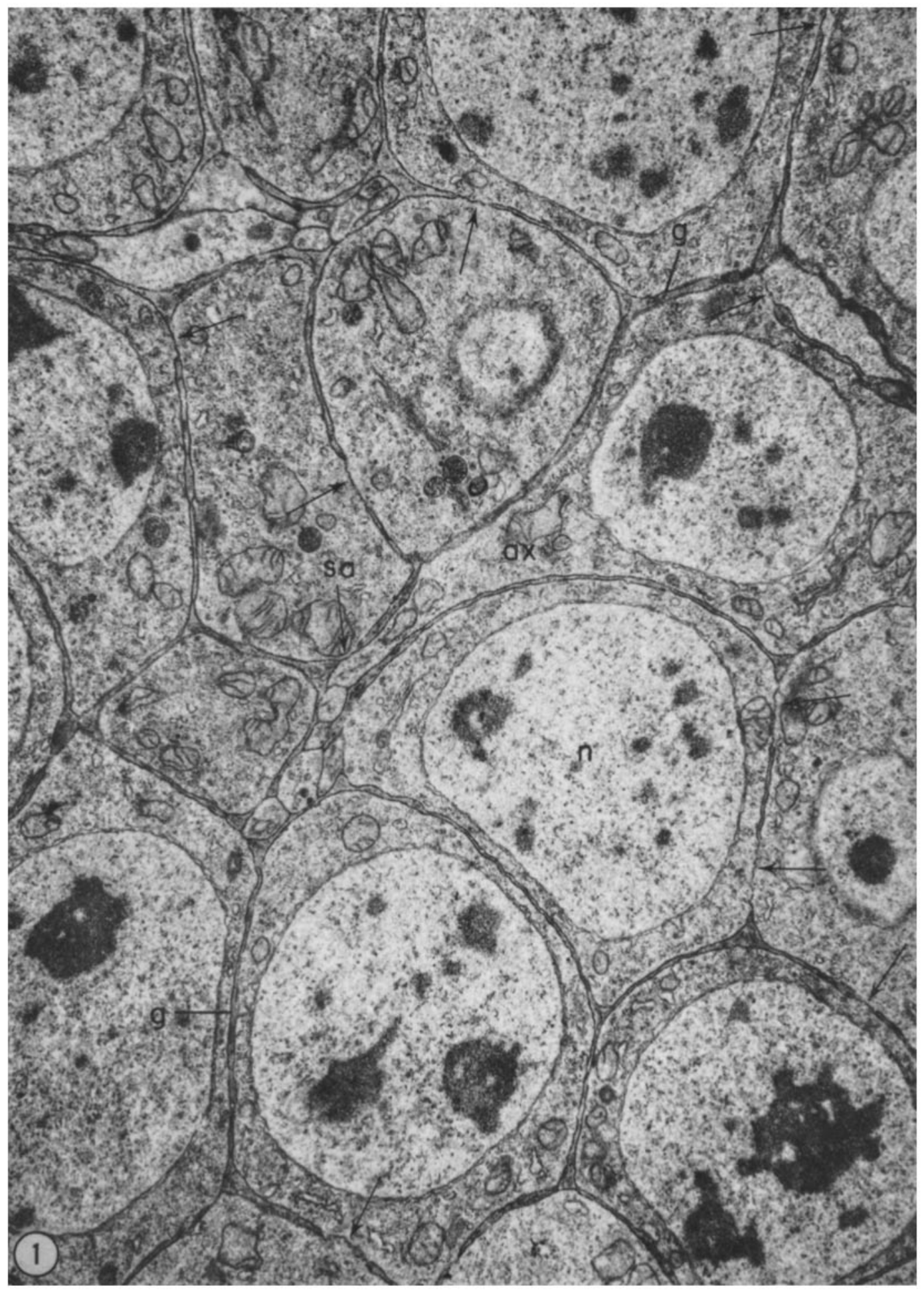

FIGURE 1 Low power micrograph of mushroom body of ant showing an area containing several neurons with big roundish nuclei $(n)$, mitochondria, Golgi complexes, multivesicular bodies, and tubes of the endoplasmic reticulum. The neurons are separated by thin glial sheaths (g). Arrows mark interruptions of glial sheaths (glial windows) that enable the neurons to make direct, soma-somatic contacts. At $a x$ is point of origin of an axon which shows a soma-axonic contact (arrow sa). Permanganate fixation; uranyl acetate and lead hydroxide staining. $\times 15,000$. 


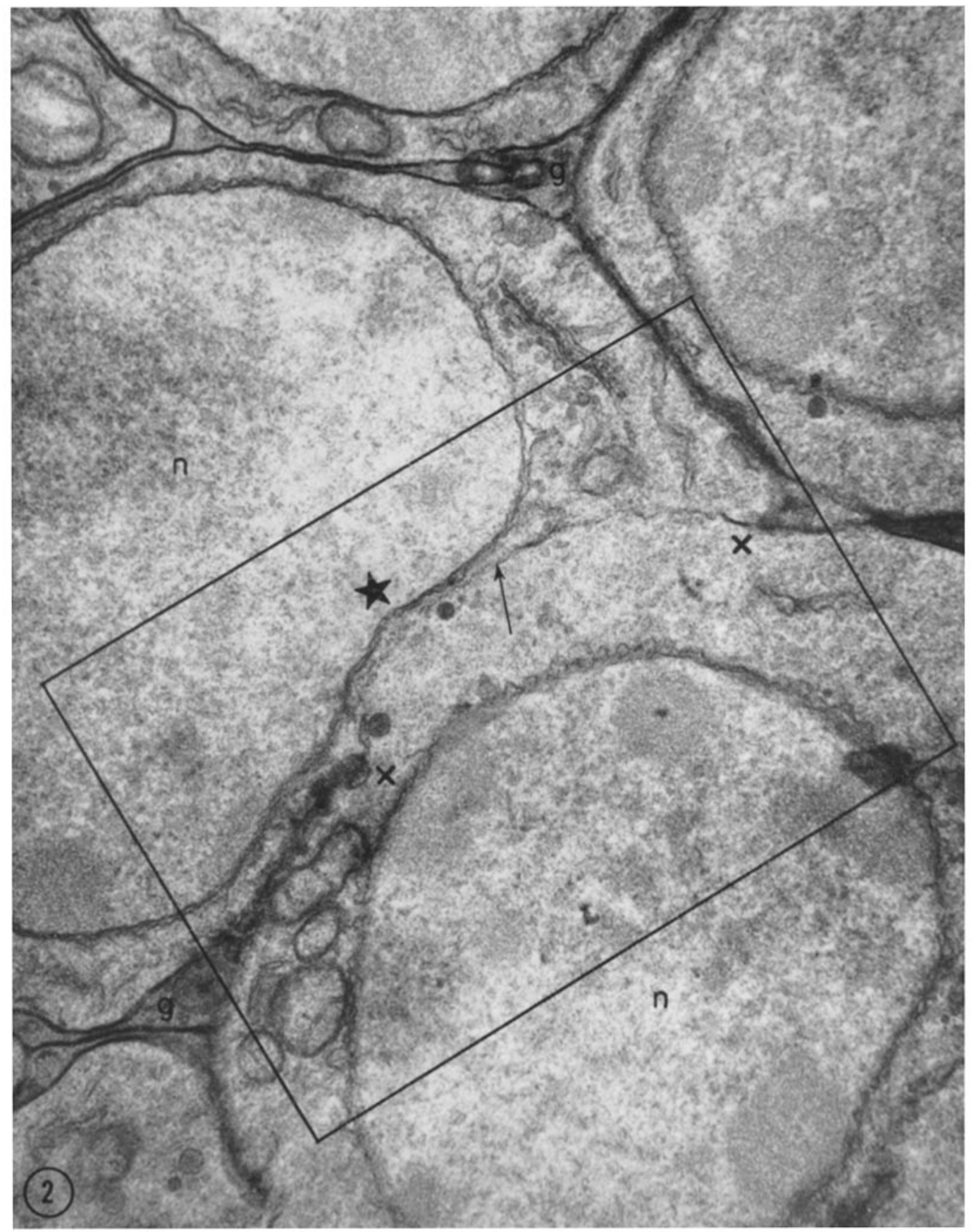

Figure 2 General view of area (in rectangle) sectioned serially and illustrated in Figs. 3 to 10. Direct contact (arrow) is shown between two neurons in the region of a glial window whose margins are marked with crosses. The contact surface bulges into one cell and causes a depression of the nucleus (starlet). $n$, nucleus; $g$, glial sheath. Permanganate fixation; lead citrate staining. The section shown here is located between those of Figs. 7 and 8 ; the distance between this section and that shown in Fig. 3 measures approximately $1.8 \mu$. $\times 21,000$. 
followed by osmium tetroxide (Dalton, 1955) according to a previously described method (Landolt, 1965). After dehydration in ethanol, the specimens were embedded in Epon 812 according to Luft (1961). Dark gray or silver-colored sections were cut with glass knives on a Porter-Blum microtome. The sections were collected on copper grids covered with carbon-coated collodion films and were stained with uranyl acetate (Watson, 1958) and lead hydroxide (Karnovsky's method B, 1961). Serial sections with a thickness of about $1500 \mathrm{~A}$ were picked up with a formvar film on a wire loop and orientated, with the aid of a dissecting microscope, on single-hole grids having an opening of $2.0 \times 1.0 \mathrm{~mm}$. The sections were stained with lead citrate (Reynolds, 1963) and coated with a layer of evaporated carbon. Electron micrographs were prepared with a Siemens Elmiskop I at $80 \mathrm{kv}$ using the double condensor. The condensor aperture was either 400 or $200 \mu$, and the objective aperture 50 or, rarely, $30 \mu$. Primary magnifications were from 4,000 to 80,000 . All exposures were made on Scientia 23 D 50 plates.

\section{RESULTS}

\section{Soma-Somatic Junctions}

Fig. 1 illustrates that the glial tissue surrounding the individual nerve perikarya is discontinuous, enabling the neurons to make direct contact over areas as wide as $4 \mu$ in diameter. In order to clarify the structural relations of such interneuronal junctions, an analysis of serial sections was made. Such a junction is shown in Fig. 2, and Figs. 3 to 10 are sample micrographs of an uninterrupted series of 22 sections through that area. The first section (Fig. 3) shows a continuous glial sheath between two neurons. The close proximity between cell membrane and nucleus of the upper neuron (circle) is quite striking. The section shown in Fig.
4 is separated from the first one by about $0.15 \mu$. The glial sheath is sectioned obliquely and appears less well defined (arrow). In the following sections (Figs. 5 to 9) a hole appears in the glial sheath which increases in size (up to Fig. 7) and then decreases again (Figs. 8 to 9). In Fig. 10 the gap in the glial process has disappeared. The analysis of serial sections through such gaps has convinced us that only one glial cell is involved and that the gap represents an intracellular window rather than a space between adjacent cells. The thickness of the glial sheath is approximately $250 \mathrm{~A}$ and the hole measures approximately $2.85 \mu$ in one direction and $3.30 \mu$ in the other (the latter measurement was based on the assumption that the average section is $0.15 \mu$ thick). We shall refer to these gaps as "glial windows". Inside these glial windows one finds soma-somatic junctions. Two features of these junctions deserve mentioning: 1) The contact surface of two nerve cell bodies usually bulges into one cell or the other. The surface is usually crinkled so that profiles may appear wavy (Figs. 5, 6) or even interrupted (Figs. 7, 8). 2) The junctions often appear to have a close relationship to the nucleus of one cell (Fig. 7) or both cells (Fig. 11). In some instances, the nucleus of one neuron is slightly depressed in the area of the bulge (Figs. 2, 7, 8). The space between nuclear membrane and cell membrane may be as narrow as $200 \mathrm{~A}$. No specific and consistent relations between the junction and other cellular elements (such as mitochondria, Golgi apparatus, endoplasmic reticulum, ribosomes, inclusion bodies, etc.) can be seen. Nor is there an accumulation of vesicles in the cytoplasm associated with these soma-somatic junctions.

Frgures 3 to 10 Sample micrographs of an uninterrupted series of 22 sections, showing the framed area of Fig. 2. Note the striking approximation of the membrane of the upper neuron $(o)$ to its nucleus, even beyond the region of the junction. A hole appears in the glial sheath (between Figs. 4 and 5), increases in size (up to Fig. 7), and then decreases again (Figs. 8 to 9). In Fig. 10 the glial gap has disappeared. Note origin of the axon from the upper neuron in Fig. 8. Fig. 9 shows a blurred picture of the obliquely cut membrane (between arrows). All labels and preparation methods are the same as in Fig. 2 . Distances of the various sections from the section shown in Fig. 3:

Fig. 4, about $0.15 \mu \quad$ Fig. 7, about $1.50 \mu$

Fig. 5 , about $0.30 \mu \quad$ Fig. 8 , about $2.40 \mu$

Fig. 6, about $0.90 \mu \quad$ Fig. 9, about $3.00 \mu$

Magnification, $\times 13,000$.

Fig. 10, about $3.60 \mu$ 

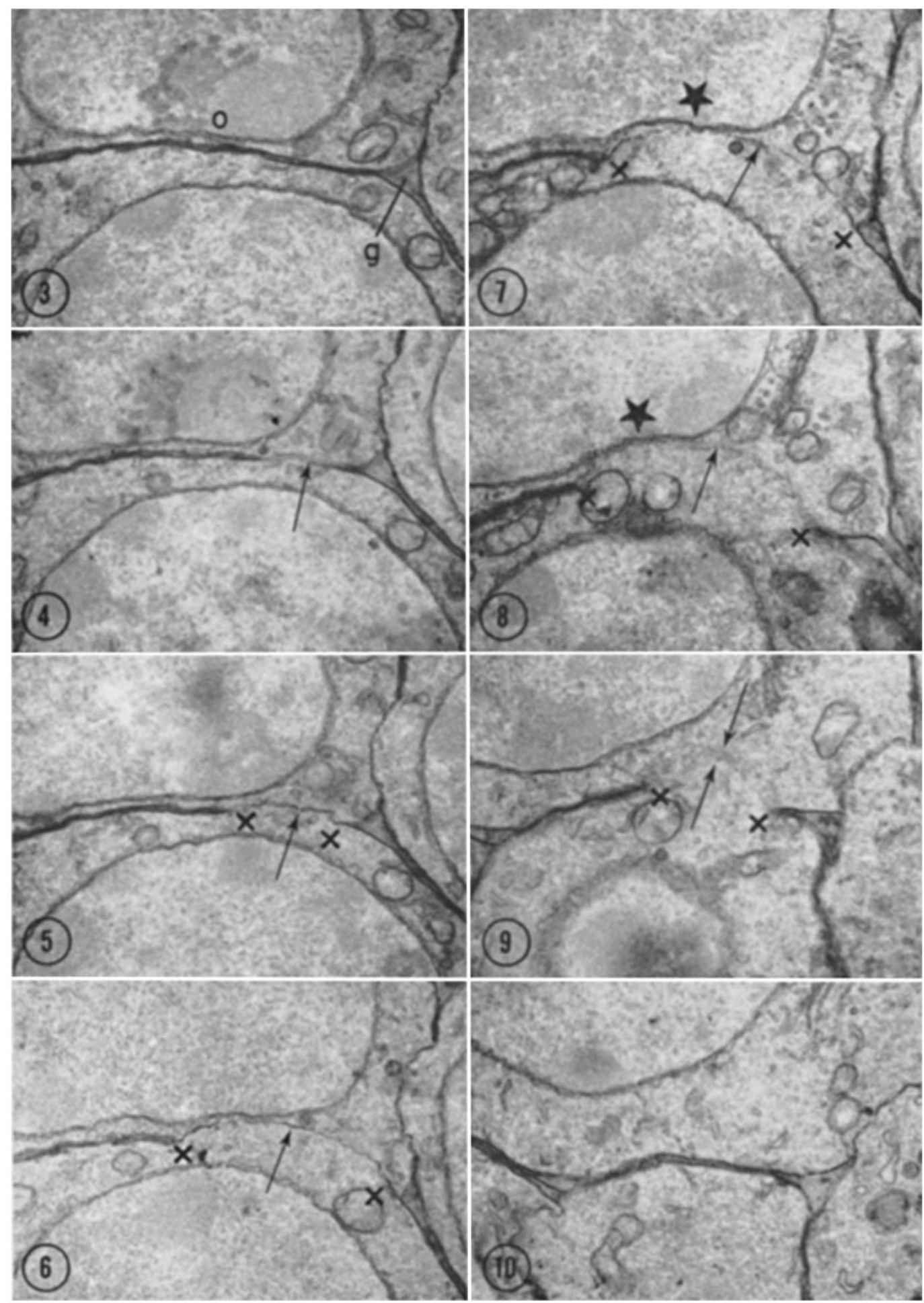

A. M. Landolt AND H. Ris Soma-Somatic Interneuronal Junctions 


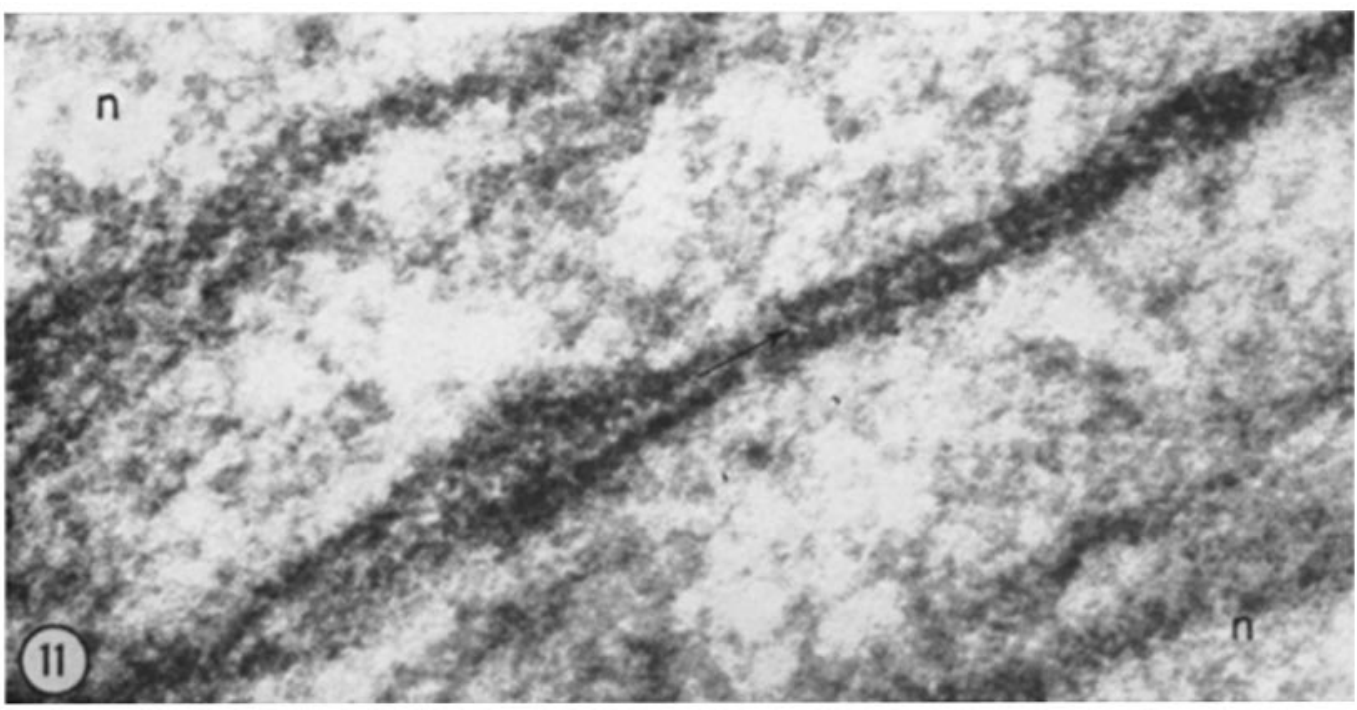

Frgure 11 Soma-somatic junction in symmetrical, close position between two nuclei $(n)$. The distance from the junction to the nuclear membrane measures 600 to $900 \mathrm{~A}$. The very narrow intercellular cleft (arrow) has a diameter of about $40 \mathrm{~A}$. Permanganate fixation; uranyl acetate and lead hydroxide staining. $\times 290,000$

TABLE I

Dimensions of Unit Membranes and Intercellular Spaces at Soma-Somatic Junctions Measured in Through-Focus Series

\begin{tabular}{|c|c|c|c|c|}
\hline & $\begin{array}{c}\text { Diameter } \\
\text { mean }\end{array}$ & $\begin{array}{c}\text { No. of } \\
\text { meas- } \\
\text { ure- } \\
\text { ments }\end{array}$ & $\begin{array}{l}\text { Standard } \\
\text { deviation }\end{array}$ & $\begin{array}{c}\text { Variation } \\
\text { coefficient }\end{array}$ \\
\hline Unit membrane & $87 \mathrm{~A}$ & 30 & $13 \mathrm{~A}$ & $15 \%$ \\
\hline $\begin{array}{l}\text { Intercellular } \\
\text { space }\end{array}$ & $31 \mathrm{~A}$ & 30 & $22 \mathrm{~A}$ & $71 \%$ \\
\hline
\end{tabular}

Dimensions of the Unit Membranes and the Intercellular Cleft at the Soma-Somatic Junctions

Since the membranes in the junctions are rarely smooth but generally wavy, high resolution electron micrographs of membranes sectioned at right angles are rarely obtained. In favorable sections, however, it is striking that the intercellular space is extremely narrow (Fig. 11). Occasionally, the membranes touch, giving rise to an "external compound membrane" (Robertson, 1958) as seen in Fig. 16. In order to obtain more reliable data on these soma-somatic junctions, the dimensions of membraries and intercellular spaces were measured in several through-focus series. No significant difference was found between material fixed with permanganate and that fixed with glutaraldehyde followed by osmium tetroxide, confirming earlier observations on glial and neuronal membranes in the central nervous system of ants (Landolt, 1965). The data were, therefore, combined, with no reference to fixation, and are presented in Table I. The thickness of the intercellular space varies between 0 and $80 \mathrm{~A} .93 \%$ of the values are within 0 and $60 \mathrm{~A}$. The value of $0 \mathrm{~A}$ cannot be taken in an absolute sense; in view of the limit of resolution, it merely means that the intercellular space is less than 10 to $15 \mathrm{~A}$.

\section{The Subunit Structure of the Soma-Somatic Junctions}

Examination of the fine structure of these junctions reveals a pattern of regularly arranged dark and light lines crossing the membranes at right angles. This pattern can be more clearly detected in junctions which are sectioned slightly obliquely. It is found regardless of whether the material was fixed in permanganate or in osmium tetroxide (Fig. 15). The pattern also persists throughout an entire through-focus series (Figs. 12 to 14). The periodicity of the lines averages $60 \mathrm{~A}$ (range, 50 to $70 \mathrm{~A})$. In selected areas in which "external compound membranes" can be found, the subunit pattern consists of three electron-opaque lines, the middle line being thicker than the other two. These 


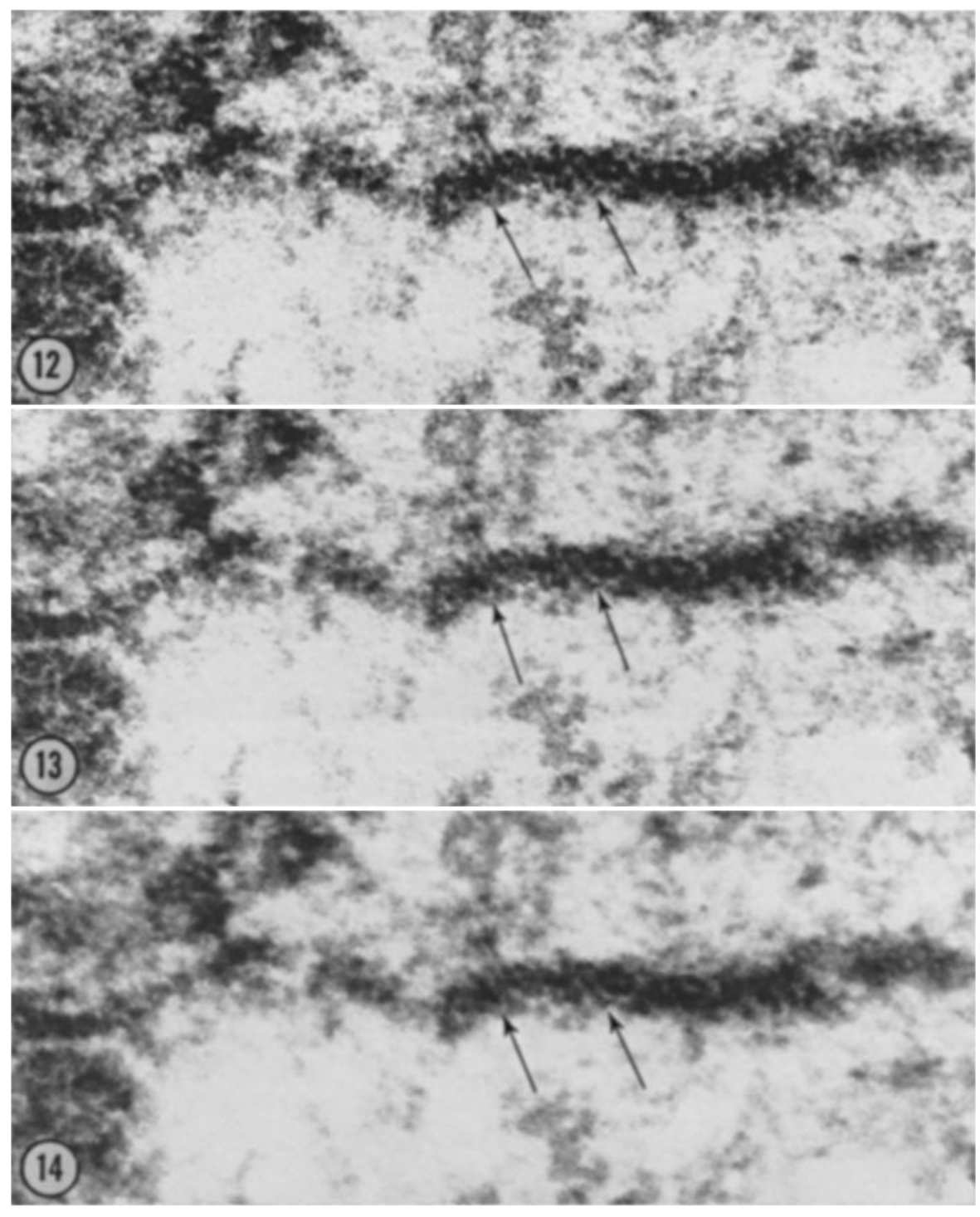

Figures 12 to 14 Through-focus series, showing detail of a soma-somatic junction with a clearly visible subunit pattern (arrows), which fails to be blurred by defocusing. Fig. 12, underfocused; Fig. 13, nearest to focus; Fig. 14, overfocused. Lens current difference $\frac{\Delta I}{I}$ from one micrograph to the next, $8.0 \times 10^{-5}$.

Period of the pattern is about $60 \mathrm{~A}$. Permanganate fixation; uranyl acetate and lead hydroxide staining. $\times 310,000$.

lines are interconnected by very fine cross-bars in a rope-ladder fashion (Fig. 16).

\section{Surface Area and Distribution of Soma- Somatic Junctions}

A layer of cells from a mushroom body measuring approximately $20 \times 14 \times 7 \mu$ was serially sec- tioned at $0.15 \mu$. It contained 26 completely sectioned boundaries between neuron pairs separated by glial sheaths. Of these, only 11 showed somasomatic junctions (i.e. $42 \%$ ). Seven had one junction each, three had two junctions, and one had three separate junctions. This indicates that while such junctions occur relatively frequently (Fig. 1) 


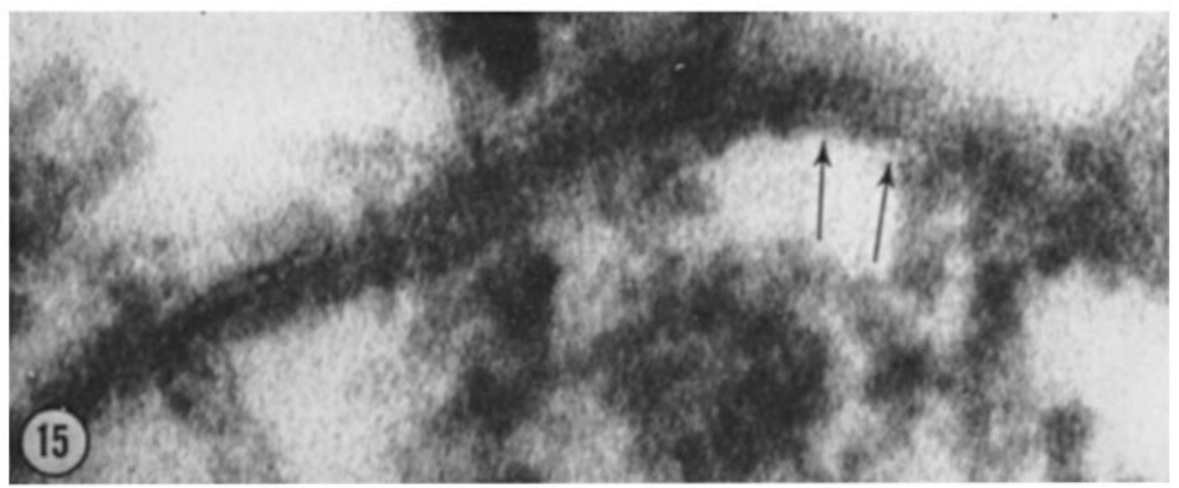

FIGURE 15 Detail of a soma-somatic junction with clearly visible subunit pattern (arrows), period 65 A. The micrograph is slightly underfocused. Glutaraldehyde and osmium tetroxide fixation; uranyl acetate and lead hydroxide staining. $\times 260,000$.

they do not occur between all neuron pairs. In two cases, we found a junction between soma and an axon (Fig. 1, arrow marked sa). The surface areas of 48 serially sectioned soma-somatic junctions were determined and a histogram of the size frequencies was prepared (Fig. 17). The mean value was found to be $2.64 \mu^{2}$. On the basis of this mean, a Poisson distribution was calculated and projected upon the same diagram (Fig. 17). The two curves do not differ significantly if the single exceptionally large window is not included in the statistical analysis.

\section{DISCUSSION}

\section{Soma-Somatic Junctions in the Perikaryon Layer of the Mushroom Body in Ants}

Reconstructions based on serial electron micrographs of the mushroom body of the wood ant reveal that the glial cell processes separating neuron cell bodies form a complex network of extremely thin lamellae. The glial sheaths contain round gaps or windows of varying size through which neurons make direct contact with each other. These somasomatic junctions are approximately the size of vertebrate synapses. This type of junction between neurons is very unusual and has been found only in one other case by electron microscopists. Hopsu and Arstila (1965) described somato-somatic synaptic structures in the pineal gland in the rat. These structures were characterized by electronopaque projections from the cell membrane surrounded by small vesicles. The soma-somatic junctions in the ant brain clearly differ from those in the pineal gland, in that cytoplasmic vesicles or membrane thickenings are absent. Furthermore, the space between the membranes is often decreased in the junctions of the ant, whereas in the pineal gland of the rat there is no apparent change in the intercellular space at the synapse.

The glial windows and interneuronal junctions described in this paper bear striking resemblance to formations described in the octopus (Hama, 1962) and in the crayfish (Robertson, 1953, 1954, 1955, 1961; de Lorenzo, 1960; Hama, 1961). In these organisms, the giant nerve cells and motoneurons are separated by Schwann cell sheaths which contain holes through which interneuronal contacts are made. Hama (1961) uses the term "cribriform" synapses and Watanabe and Grundfest (1961) use the term "window," in describing the junctions seen in the lateral giant fibers of the crayfish. There are, however, three significant differences between the windows just mentioned and those in the mushroom body of the ant: 1) The interneuronal sheaths of crayfish and octopus are considerably thicker ( 2 to $10 \mu$ ) than the corresponding glial processes in the ant $(0.1$ to $0.2 \mu)$. 2) The sheaths of the crayfish and octopus consist of several layers of Schwann-cell processes with interspersed connective tissue (Hama, 1961, 1962). Towards the window, the sheath is thinned out somewhat and the "frame" is made up of but one cellular process. However, the evidence for intracellular gap-formation has never been presented, and it remains an open question as to whether one single cell (as in the ant) or more cells are involved. 3) The fenestrated sheaths of octopus and crayfish 


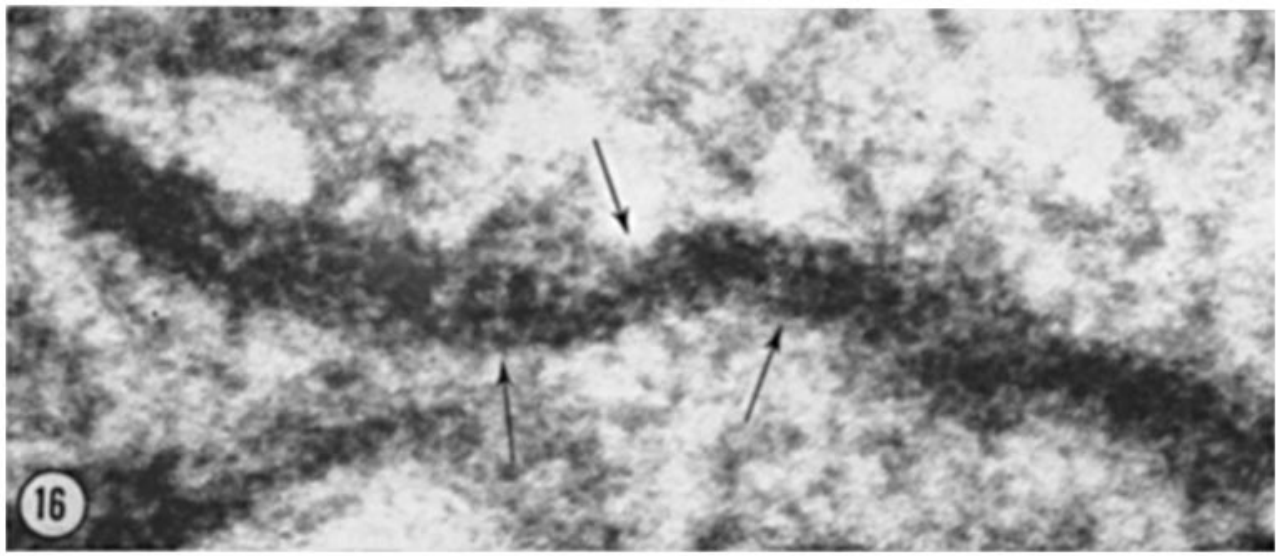

Frgune 16 Detail of a soma-somatic junction with clear subunit pattern, period 70 A. Formation of an "external compound membrane" (arrows). Permanganate fixation; uranyl acetate and lead hydroxide staining. $\times 340,000$.

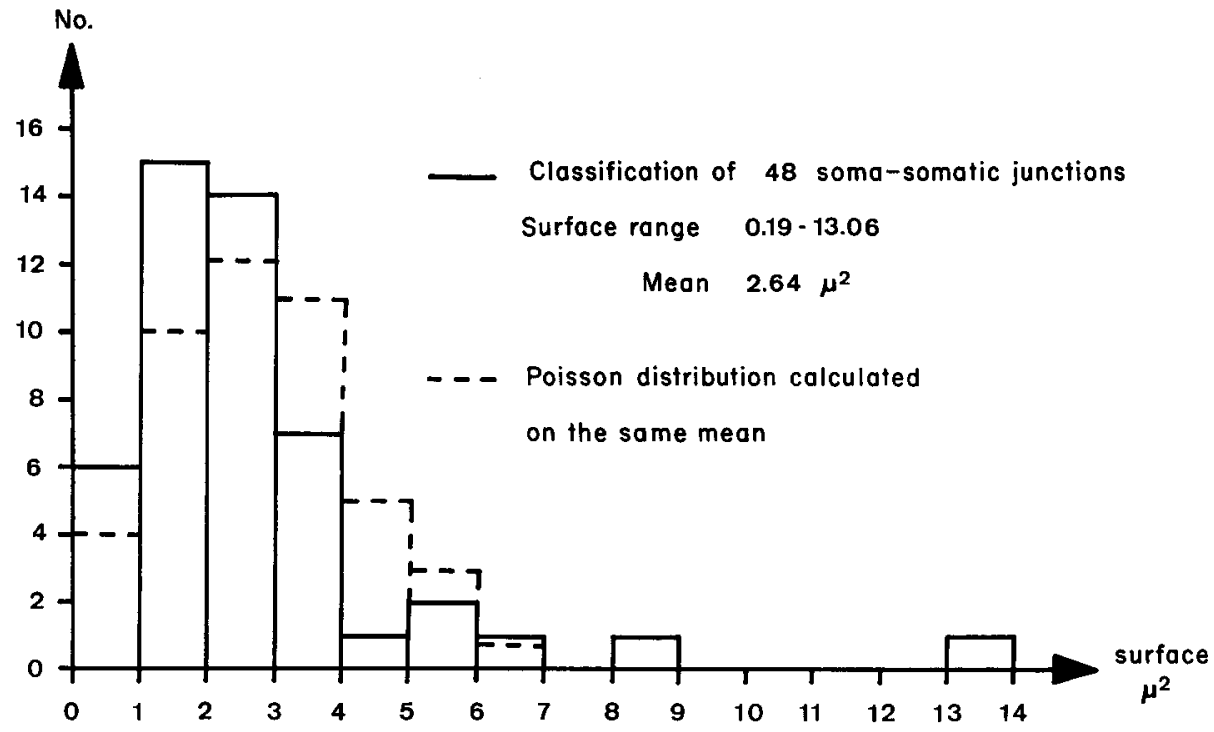

Figure 17 Histogram showing the area classification of 48 soma-somatic junctions and the Poisson distribution of a population calculated on the same mean value.

are found between axons, whereas the junctions described here in ants are of soma-somatic nature.

The observations reported here may explain Haller's (1905) finding of "intercellular bridges" between neurons in the mushroom bodies of certain insects (Blatia orientalis L., and Apis mellifica L.). That author believed that these "bridges" demonstrated the existence of a neuronal syncytium (Fig. 18), and entered upon a violent argument with protagonists of the neuron theory (His, 1886; Forel, 1887; Ramón y Cajal, 1888; and
Waldeyer, 1891). Under conditions of faulty fixation, similar "intercellular bridges" were visible in our material. The "bridges" resulted from a separation of the perikarya along the glial linings except at areas of interneuronal contact (Fig. 19, arrows). Haller could not resolve the 200-A interneuronal wall with the light microscope and so was misled to interpret these close contacts between cells as "intercellular bridges."

The evidence presented here in favor of interneuronal junctions in the perikaryon layer of the 


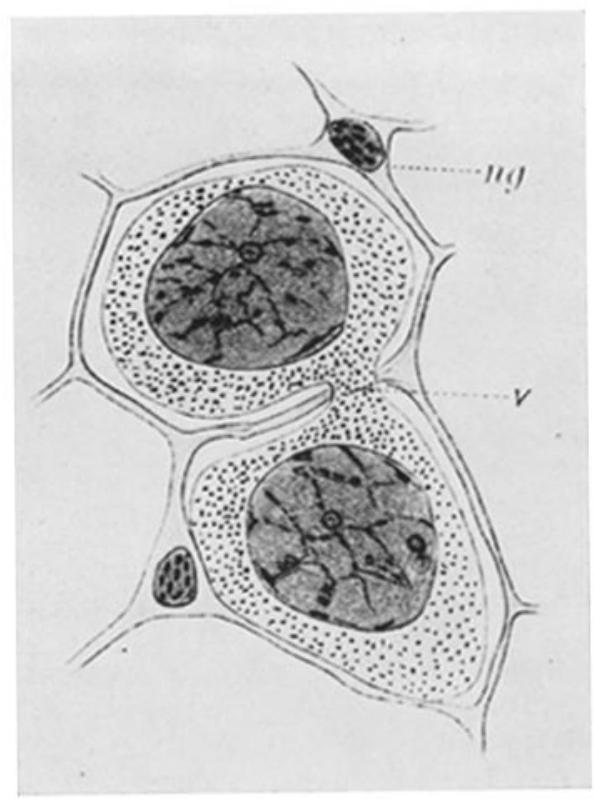

Figure 18 B. Haller's figure showing an interneuronal connection $(v)$ in the medial part of the optic lobe of Blatta occidentalis L. $n g$, glial nucleus (From Arch. mikr. Anat., 1905, 65, 181).

ant's mushroom body is of particular importance, since contacts between nerve cells have been found, so far, only in the underlying synaptic layer of the neuropil (Hess, 1958; Trujillo-Cenóz, 1959, Trujillo-Cenóz and Melamed, 1962; Smith and Treherne, 1963; Arnold, 1964; Basurmanova, 1964; Buchholz, 1964). These axo-axonic and axodendritic synapses closely resemble the analogous junctions in the vertebrate ganglia. However, the soma-somatic junctions in the ant brain represent a fundamentally different type not heretofore described in the vertebrate brain.

\section{The Functional Significance of Soma-Somatic Junctions and Glial Windows}

The function of these junctions cannot be assessed on the basis of morphological studies. Nevertheless, the present data seem to provide interesting suggestions for physiological research.

\section{Chemical or Electrical Transmission?}

The structure of the soma-somatic junctions suggests that they may play a role in interneuronal transfer of information. The typical signs of chemical transmission (agglomeration of vesicles and mitochondria) are missing. In contrast, the morphological findings seem to favor the presence of electrical transfer since they simulate many, if not all, essential features described in physiologically identified electrical junctions in other species. Studies on electrical junctions have shown that they are characterized by a diminished width of the synaptic cleft as well as by a typical crossdirectional "subunit pattern" in the junctional membranes (Robertson, 1955, 1961; Kao and Grundfest, 1957; Furshpan and Potter, 1959; Hama, 1959; de Lorenzo, 1960; Hama, 1961; Watanabe and Grundfest, 1961; Robertson, 1963; Robertson, Bodenheimer, and Stage, 1963; Bennett, Aljure, Nakajima and Pappas, 1963; Furshpan, 1964). The synaptic cleft in electrical junctions measures less than $100 \mathrm{~A}$. The somasomatic junctions of the ant brain described here also show a narrow cleft. On the average, it measures $30 \mathrm{~A}$. Occasionally, an external compound membrane may be encountered. This approximation of junctional membranes might serve to enhance electrical transmission, although other factors such as membrane resistance and membrane excitability are important (Watanabe and Grundfest, 1961; van der Loos, 1963; Loewenstein and Kanno, 1964).

Another indication that we might be dealing with an electrical junction is the presence of a "subunit pattern," a 50- to 70-A periodicity, in the synaptic membranes. Similar observations were made on a variety of membranes by FernándezMorán (1962), Pease (1962), Robertson (1963). Fernández-Morán, Oda, Blair, and Green (1962), Kelly and Smith (1964), Nilsson (1964), Robertson, Lolley, and Lamborghini (1964), and Sjöstrand and Elfvin (1964). The similarity between the soma-somatic junction shown in Fig. 16 and the structure described by Robertson (1963) for the club endings of the Mauthner cell is particularly striking.

\section{Relationship Between Soma-Somatic Junctions and Cell Nucleus}

The close proximity of interneuronal junctions and the cell nucleus has not been noticed before in other types of synapses. Its significance is not clear. On one hand, the cytoplasm of these neurons is admittedly narrow and the proximity of the 


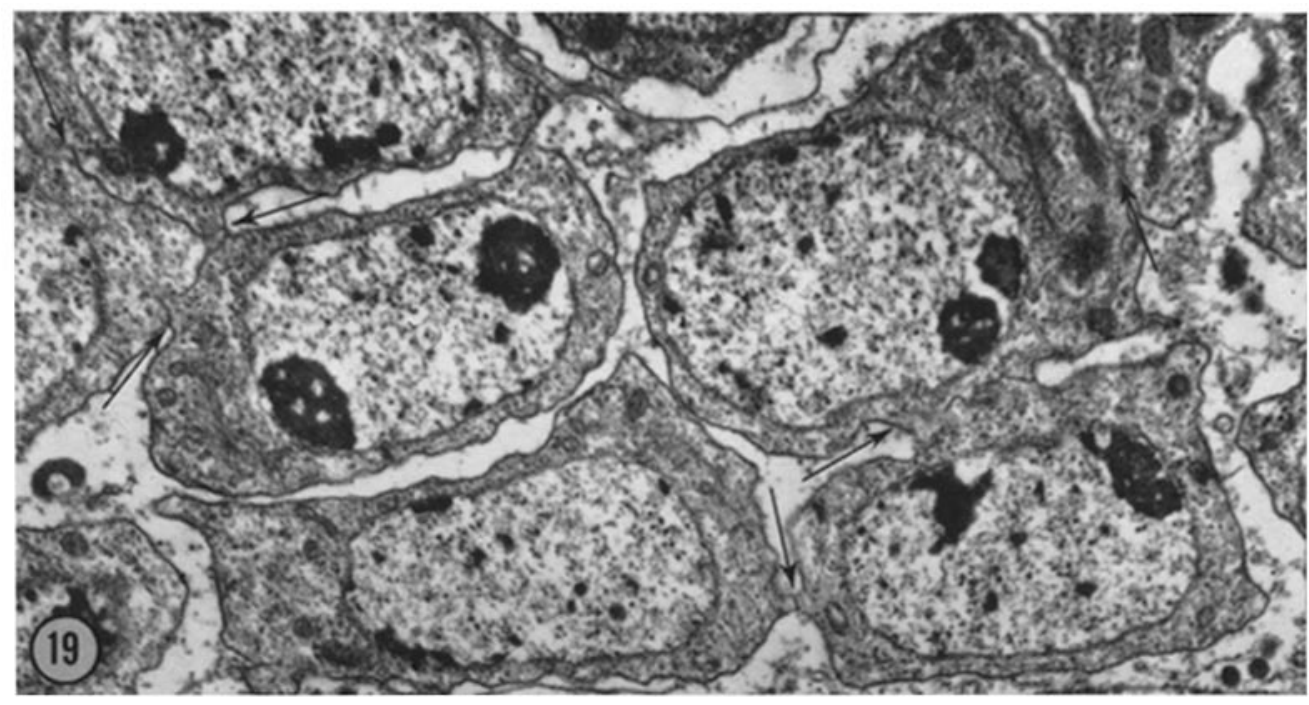

FIGURE 19 Swelling of the glial processes, due to unsatisfactory fixation, reveals that neurons stick together in certain places (arrows). Higher magnification shows that these represent soma-somatic junctions.

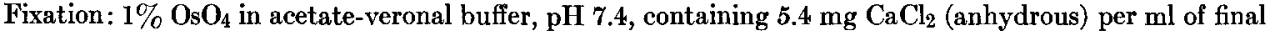
solution. Uranyl acetate and lead hydroxide staining. $\times 10,000$.

nucleus and the junctions may be purely accidental. On the other hand, one should remember that certain modern theories on memory attribute a specific role to nuclear DNA in the process of engram formation (Hydén, 1964).

\section{The Role of Guial Windows: Static or Dynamic?}

Glial windows determine the range of contacts between neurons. The question arises as to whether these windows are ontogenetically determined and remain of constant size or whether they may appear and disappear during the life of the organism. The significance of this problem is better understood if one realizes that electrical synapses, unlike their chemical counterparts, are less equipped for quantitative and directional control of information flow. If the glial windows could vary in size and position, the glial tissue might serve some regulatory functions in respect to information transfer. In conventional theory, such function has been attributed exclusively to neurons (for an exception, see Galambos, 1961).

At the present time, there is no direct evidence to support the notion of dynamic properties of glial windows. Nevertheless, two observations may be relevant: 1) The fact that, in a given neuron pool, only $42 \%$ of the adjacent neurons were interconnected by soma-somatic junctions may indicate that a selection mechanism favoring the connections along certain pathways is at work. 2) It has been demonstrated by several authors, notably by Pomerat (1958), that glial cells (at least in tissue culture) have dynamic properties. Furthermore, Birks (1962) showed that Schwann cell elements may expand into the synaptic cleft at the motor endplates of frog skeletal muscle (under the influence of glycosides).

Physiological researches are now necessary to determine whether the soma-somatic junctions in the mushroom body of ants are electrical junctions and whether variations in size and distribution of glial windows are related to the regulation of neuron interaction.

This work was supported by grant 2575 from the Swiss National Foundation for Scientific Research. It was conducted while Dr. Ris was a visiting scientist at the Institute for Brain Research.

Received for publication 23 August 1965. 


\section{REFEREN CES}

Arnold, W. J., 1964, Structural organization in the neuropile of the Periplaneta brain, J. Cell Biol., 23, $6 \mathrm{~A}$.

Basurmanova, O. K., 1964, Distinctive features of fine structure of the conducting elements of cerebral ganglion in insects. Fed. Proc., Suppl., 23, T 1177.

Bennett, M. V. L., Aljure, E., Nakajima, Y., and PAPPAS, G. D., 1963, Electrotonic junctions between teleost spinal neurons: electrophysiology and ultrastructure, Science, 141, 262.

BIRks, R. I., 1962, The effects of a cardiac glycoside on subcellular structures within nerve cells and their processes in sympathetic ganglia and skeletal muscle, Canad. J. Biochem. and Physiol., 40, 303.

Bughнolz, Сн., 1964, Elektronenmikroskopische Befunde am bestrahlten Oberschlundganglion der Odonaten-Larven, $Z$. Zellforsch. u mikr. Anat., 63, 1.

Dalton, A. J., 1955, A chrome osmium fixative for electron microscopy, Anat. Rec. 121, 281.

De Lorenzo, A. J., 1960, Electron microscopy of electrical synapses in the crayfish, Biol. Bull., 119, 325.

Fernández-Morán, H., 1962, Cell membrane ultrastructure: low-temperature electron microscopy and X-ray diffraction studies of lipoprotein components in lamellar systems. Res. Pub. Assn. Nerv. and Ment. Dis., 40, Ultrastructure and metabolism of the nervous system.

Fernández-Morán, H., Oda, T., Blair, P. V., and Green, D. E., 1964, A macromolecular repeating unit of mitochondrial structure and function, $J$. Cell Biol., 22, 63.

Forel, A., 1887, Einige hirnanatomische Betrachtungen und Ergebnisse, Arch. Psychiat. Nervenkrankh., 18, 162.

Furshpan, E. J., 1964, "Electrical transmission" at an excitatory synapse in a vertebrate brain, Science, 144, 878.

Furshpan, E. J., and Potter, D. D., 1959, Transmission at the giant synapses of the crayfish, $J$. Physiol. (Lond.), 145, 289.

Galambos, R., 1961, A glia-neural theory of brain function. Proc. Nat. Acad. Sc., 47, 129.

Haller, B., 1905, Ueber den allgemeinen Bauplan des Tracheatensyncerebrums, Arch. mikr. Anat. Entwgesch., 65, 181.

Hama, K., 1959, Some observations on the fine structure of the giant nerve fibers of the earthworm Eisenia foetida, J. Biophysic. and Biochem. Cytol., 6, 61.

Hama, K., 1961, Some observations on the fine structure of the giant fibers of the crayfishes (Cambarus virilis and Cambarus clarkii) with special reference to the submicroscopic organization of the synapses, Anat. Rec., 141, 275.

Hama, K., 1962, Some observations on the fine struc- ture of the giant synapse in the stellate ganglion of the squid, Dorytenphis bleekeri, $Z$. Zellforsch., 56, 437.

Hess, A., 1958, 'The fine structure of nerve cells and fibers, neuroglia, sheaths of the ganglion chain in the cockroach, J. Biophysic. and Biochem. Cytol., 4, 731.

His, W., 1886, Zur Geschichte des menschlichen Rückenmarkes und der Nervenwurzeln, Abhandlg. K. Sächs. Ges. Wissensch., Math.-phys. Cl., 13, 477.

Hopsu, V. K., and Arstil A, A. U., 1965, An apparent somato-somatic structure in the pineal gland of the rat, Exp. Cell Research, 37, 484.

Hyden, H., 1964, Biochemical and functional interplay between neurons and glia, in Recent Advances in Biological Psychiatry, (J. Wortis, editor), New York, Plenum Press.

Kao, C. Y., and Grundfest, H., 1957, Postsynaptic electrogenesis in giant axons. I. Earthworm median giant axons, $J$. Neurophysiol., 20, 553.

KaRnovsky, M. J., 1961, Simple methods for "staining with lead" at high $\mathrm{pH}$ in electron microscopy, J. Biophysic. and Biochem. Cytol., 11, 729.

Kelly, D. E., and Smith, S. W., 1964, Fine structure of the pineal organs of the adult frog, Rana pipiens, J. Cell Biol., 22, 653.

LANDOLT, A. M., 1965, Elektronenmikroskopische Untersuchungen an der Zellkörperschicht der Corpora pedunculata von Waldameisen (Formica lugubris Zett.) mit besonderer Berücksichtigung der Neuron-Glia-Beziehung, Z. Zellforsch, 66, 701 .

Loewenstern, W. R., and Kanno, Y., 1964, Studies on an epithelial (gland) cell junction. I. Modifications of surface permeability, $J$. Cell. Biol., 22, 565 .

LufT, J. H., 1961, Improvements in epoxy resin embedding methods, J. Biophysic. and Biochem. Cytol., 9, 409.

Nilsson, S. E. G., 1964, Receptor cell outer segment development and ultrastructure of the disc membranes in the retina of the tadpole (Rana pipiens), J. Ultrastruct. Research, 11, 581 .

Palay, S. L., MaGee-Russell, S. M., Gordon, S., and Grillo, M. A., 1962, Fixation of neural tissues for electron microscopy by perfusion with solutions of osmium tetroxide, J. Cell Biol., 12, 385.

Pease, D. C., 1962, Demonstration of a highly ordered pattern upon a mitochondrial surface, $J$. Cell Biol., 15, 385.

Pomerat, Ch. M., 1958, Functional concepts based on tissue culture studies of neuroglia cells, in Biology of Neuroglia, (W. F. Windle, editor), Springfield, Thomas.

Ramon y Cajal, S., 1888, Estructura de los centros nerviosos de las aves, cit. from Trav. lab. rech. biol., 1935, 30, 102 .

Reynolds, E. S., 1963, The use of lead citrate at high 
$\mathrm{pH}$ as an electron-opaque stain in electron microscopy, J. Cell Biol., 17, 208.

Robertson, J. D., 1953, Ultrastructure of two invertebrate synapses, Proc. Soc. Exp. Biol. and Med. 82, 219.

Robertson, J. D., 1954, Electron microscope study of an invertebrate synapse, Fed. Proc., 13, 119.

Robertson, J. D., 1955, Recent electron microscope observations on the ultrastructure of the crayfish median-to-motor giant synapse, Exp. Cell Research, 8, 226.

Robertson, J. D., 1958, Structural alterations in nerve fibers produced by hypotonic and hypertonic solutions, J. Biophysic. and Biochem. Cytol., 4, 349.

Robertson, J. D., 1961, Ultrastructure of excitable membranes and the crayfish median-giant synapse, Ann. New York Acad. Sc., 94, 339.

Robertson, J. D., 1963, The occurrence of a subunit pattern in the unit membranes of club endings in Mauthner cell synapses in goldfish brains, $J$. Cell Biol., 19, 201.

Robertson, J. D., Bodenheimer, T. S., and Stage, D. E., 1963, The ultrastructure of Mauthner cell synapses and nodes in goldfish brains, J. Cell Biol., $19,159$.

Robertson, J. D., LOLLEy, R. N., and LAMBoRghiNi, J. E., 1964, Variations in unit membranes and experimental production of unit membrane limited vesicles, Anat. Rec., 148, 327.
Smith, D. S., and Treherne, J. E., 1963, Functional aspects of the organization of the insect nervous system, in Advances in Insect Physiology, (J. W. L. Beament, J. E. Treherne, and V. B. Wigglesworth, editors), London, Academic Press Inc.

Sjöstrand, F. S., and Elfvin, L. G., 1964, The granular structure of mitochondrial membranes and of cytomembranes as demonstrated in frozendried tissues, J. Ultrastruct. Research, 10, 263.

Trujilio-Cenòz, O., 1959, Study on the fine structure of the central nervous system of Pholus labruscae L., Z. Zellforsch., 49, 432.

Trujillo-Cenòz, O., and Melamed, J., 1962, Electron microscope observations on the calyces of the insect brain, J. Ultrastruct. Research, 7, 389.

VAN DER Loos, H., 1963, Fine structure of synapses in the cerebral cortex, $Z$. Zellforsch., 60, 815 .

Waldeyer, H. W. G., 1891, Ueber einige neuere Forschungen im Gebiete der Anatomie des Centralnervensystems, Dtsch. med. Woch., 17, 1213, 1244, 1267, 1287, 1331, 1352.

Watanabe, A., and Grundfest, H., 1961, Impulse propagation at the septal and comissural junctions of crayfish, lateral giant axons, J. Gen. Physiol., 45, 267.

Watson, M. L., 1958, Staining of tissue sections for electron microscopy with heavy metals, J. Biophysic. and Biochem. Cytol., 4, 475. 